\title{
Sosyoekonomik Gelişmişlik Düzeyinin Yolsuzluk Algı Endeksi Üzerindeki Etkisine İlişkin Bir Analiz
}

\section{An Analysis on the Relationship between the Corruption Perception Index and Various Development Indexes of the Countries}

Funda Buz $^{1}$
Melike Rana Erul $^{2}$

RESEARCH

ARTICLE

\section{ARTICLE INFO}

Submitted : 07.08.2018

Revised : 16.12.2018

Accepted : 25.12.2018

Available : 30.12.2018

JEL classification:

D73, C33

Keywords:

Corruption Perception Index, Socioeconomic Development, Panel Data Analysis

\begin{abstract}
A B S T R A C T
While corruption is defined by the World Bank as abusing its public power for private interests, it is defined in the United Nations Convention as any misuse of the entrusted authority in such a way as to damage public and private interests. Corruption has been emerged because of lots of social, managerial, economic and political reasons and has become a problem facing every country today. In the studies conducted on the corruption perception index, while the index is found to be related to many variables affecting social and economic structure, there are many different opinions in the literature about the size and direction of the relationship. Indeed, countries' corruption levels differ according to the economic and social structure. In this context, since it is thought that the corruption perception index is closely related to the development levels of the countries, in the study, the effects of various variables, which represents the levels of development, on the corruption perception index are tried to be measured.

In the study, to determine the relationship between the corruption perception index and the development indexes, the data for 120 countries are analyzed by separating the countries into three groups as low, middle and high income countries according to the classification made by the
\end{abstract}

Cite this article as: Buz, F. \& Erul M.R. (2018). "Sosyoekonomik Gelişmişlik Düzeyinin Yolsuzluk Algı Endeksi Üzerindeki Etkisine İlişkin Bir Analiz", International Journal of Public Finance, Vol.3, No.2, pp. 233-248.

${ }^{1}$ Res. Assist. (https://orcid.org/0000-0002-3156-1949), Eskişehir Osmangazi University, Faculty of Economics and Administrative Sciences, Department of Public Finance, Turkey, funda.buz@gmail.com

2 Res. Assist. (https://orcid.org/0000-0001-9073-6430), Ankara Hacl Bayram Veli University, Faculty of Economics and Administrative Sciences, Department of Public Finance, Turkey, ranadayioglu@gmail.com 
Buz, F. \& Erul M.R. (2018). "Sosyoekonomik Gelişmişlik Düzeyinin Yolsuzluk Algı Endeksi Üzerindeki Etkisine İlişkin Bir Analiz", International Journal of Public Finance, Vol.3, No.2, pp. 233-248.

World Bank and are analyzed by panel data analysis method including 2007-2016 period. Economic development, governance, level of education, political stability and social capital indexes are considered as variables that are thought to represent countries' socioeconomic development. In the analysis results; we find out that socioeconomic factors which determine community structure have a significant effect on the corruption perception index. Especially the fact that the governance variable is highly economically and statistically significant for all country groups shows that it is the most important variable in policy determination for the prevention of corruption activities.

\begin{tabular}{l} 
MAKALE Bígisi \\
\hline Gönderme: 07.08 .2018 \\
Düzeltme $: 16.12 .2018$ \\
Kabul $\quad: 25.12 .2018$ \\
Yayın $\quad: 30.12 .2018$
\end{tabular}

JEL Kodu:

D73, C33

Anahtar Kelimeler:

Yolsuzluk algı endeksi, sosyoekonomik gelişmişlik, panel veri analizi

\begin{abstract}
Ö ZE T
Yolsuzluk; Dünya Bankası tarafından kamu gücünün özel çıkarlar için kötüye kullanılması olarak tanımlanırken; Birleşmiş Milletler Yolsuzlukla Mücadele Sözleşmesi'nde, emanet edilmiş olan yetkinin, kamusal ve özel çıkarları zedeleyecek şekilde her türlü kötüye kullanımı şeklinde tanımlanmaktadır. Yolsuzluk; sosyal, yönetsel, ekonomik ve siyasi birçok nedene bağlı olarak ortaya çıkabilmekte olup günümüzde her ülkenin karşı karşıya kaldığı bir sorun haline gelmiştir.

Yolsuzluk algı endeksine yönelik olarak yapılmış olan çalışmalarda, endeksin sosyal ve ekonomik yapıyı etkileyen birçok değişken ile ilişkili olduğu tespit edilmekle birlikte; ilişkinin boyutu ve yönü konusunda literatürde pek çok farklı görüş bulunmaktadır. Nitekim ülkelerin yolsuzluk düzeyleri, sahip oldukları ekonomik ve sosyal yapıya göre farklılaşmaktadır. Bu bağlamda yolsuzluk algı endeksinin, esasen ülkelerin gelişmişlik düzeyleri ile yakından ilgili olduğu düşünüldüğünden; çalışmada, gelişmişlik düzeylerini temsil eden çeşitli değişkenlerin yolsuzluk algı endeksi üzerindeki etkisi ölçülmeye çalışılmıştır.

Çalışmada, yolsuzluk algı endeksi ile gelişmişlik endeksleri arasındaki ilişkiyi ölçmek için 120 ülkeye ait veriler Dünya Bankası tarafından yapılan sınıflandırmaya göre düşük, orta ve yüksek gelirli ülkeler olmak üzere üç gruba ayrılarak incelenmiş ve 2007-2016 dönemini kapsayacak şekilde panel veri analizi yöntemi ile analiz edilmiştir. Ülkelerin sosyoekonomik gelişmişliğini ifade ettiği düşünülen değişkenler olarak ekonomik gelişmişlik, yönetişim, eğitim düzeyi, politik istikrar ve sosyal sermaye endeksi ele alınmıştır. Analiz sonuçlarında; toplum yapısını belirleyen sosyoekonomik unsurların yolsuzluk algı endeksi üzerinde önemli düzeyde etkisi olduğu tespit edilmiştir. Özellikle yönetişim değişkeninin tüm ülke grupları için hem iktisadi hem de istatistiki olarak yüksek düzeyde anlamlı bulunması, yolsuzluk faaliyetlerinin önlenmesine yönelik politika belirlemede en önemli değişken olduğunu göstermektedir.
\end{abstract}

\section{Giriş}

Yolsuzluk; hukuk düzenini tehdit eden, toplumsal adaleti bozan ve ekonominin düzenli bir şekilde gelişimini engelleyen bir olgu olarak karşımıza çıkmaktadır. Yolsuzluk; ekonomik, sosyal, siyasal ve yönetsel birçok nedenden kaynaklanmaktadır.

Yolsuzluk, günümüzde devletin temel görevlerinden olan düzenleyicilik görevini yerine getirmesine engel olmaktadır. Piyasalarda yolsuzluk nedeniyle devlet düzenlemelerinin amaçlarında meydana gelecek sapmalar büyümeye zarar 
vermektedir (Tanzi, 1998:25). Bu durumda düzenleyici politikalar, bir taraftan yolsuzluğun artmasına neden olurken öte yandan söz konusu düzenlemelerin istenen sonuçlara ulaşmasının önünde bir engel teşkil etmektedir (Tanzi, 1998:25). Bu nedenle devletin ekonomideki rolü, ekonomi üzerindeki etkinliği ve piyasaları düzenleme görevi büyük önem taşımaktadır. Devletin düzenleyicilik görevinin aksaması; ekonomideki olumsuzlukları beraberinde getirecek, ekonomik gelişme ve kalkınmanın olumsuz etkilenmesine neden olacaktır.

Yolsuzluk, ülkelerin yalnızca ekonomik gelişmelerini ve kalkınmalarını etkilemekle kalmayıp kamu harcamalarının kombinasyonunu değiştirerek eğitim, sağlık ve sosyal yardım hizmetlerinin azalmasına da neden olabilmektedir (Delavallade, 2006:222). Bu nedenle yolsuzluğun azaltılması, ekonomik gelişmişliğin yanı sıra sosyal ve kültürel gelişmişlik açısından da katkı sağlamaktadır.

\section{Yolsuzluğun Tanımı ve Türleri}

Yolsuzluk; Dünya Bankası tarafından -en kabul görmüş haliyle- "kamu gücünün özel çıkarlar için kötüye kullanılması" şeklinde tanımlanmaktadır (The World Bank, 1997:8). Klitgaard, Dünya Bankası tanımına benzer olarak, yolsuzluğun kamu sektöründe gerçekleşen bir olgu olmasına ağırlık vererek yolsuzluğu matematiksel olarak açıklamakta ve "yolsuzluk = tekel gücü + memurların karar yetkisi - sorumluluk" formülüyle ortaya koymaktadır (Klitgaard, 1998:4). Bu tanımlara dikkat edildiğinde, yolsuzluğun kamu gücüne ve sektörüne yoğunlaşarak incelendiği görülmektedir.

Birleşmiş Milletler Yolsuzlukla Mücadele Sözleşmesi'nde yolsuzluk, "emanet edilmiş olan yetkinin, kamusal ve özel çıkarları zedeleyecek şekilde her türlü kötüye kullanımı" şeklinde tanımlanmaktadır (Özbaran, 2003:18). Tanımdan anlaşılacağı gibi yolsuzluk, kamu gücünün kötüye kullanımına ek olarak özel sektörün de tanıma dahil edilmesiyle daha geniş kapsamlı tanımlanmaya başlanmıştır ki sözleşmenin birçok kısmında da özel sektörde gerçekleşen yolsuzluğa ilişkin açıklamalar yer almaktadır.

Uluslararası Şeffaflık Örgütünün tanımında ise yolsuzluk, "emanet edilen yetkinin özel çıkar için suiistimal edilmesi" şeklindedir (Transparency International, 2017). Esasen yolsuzluğun, topluma verilen zarar ya da kendi kişisel çıkarı için yetkisini kötüye kullanma olarak algılanması gerekmektedir (Saygılığlu, 2010:24).

Yolsuzluk genel olarak, türleri itibariyle doğrudan cezai yaptırıma bağlanan yolsuzluklar (rüşvet, zimmet, irtikap, kara paranın aklanması, içeriden öğrenenlerin ticareti, dolandırıcılık, emniyeti suistimal) ve dolaylı olarak cezai yaptırıma bağlanan veya suç sayılmayan yolsuzluklar (lobicilik, rant kollama, kayırmacılık, oy ticareti, diğer nedenler [kurumsal bilginin kötüye kullanılması, anayasa ihlalleri, politik faaliyetlerde harcanan paranın kaynağının gizli tutulması, mal beyanında bulunmama veya eksik mal beyanı verme, hediye alma, hukuka aykırı dinlemeler, politik bilgi sızdırma, özellikle yerel kamu hizmetlerini yürütmekle görevli hizmet birimlerinde yaygın olarak görülen 
aşırı partizanlık, siyasi kayırmacılığın bir türü olan gönül yapma gibi eylemler de yolsuzluk türleri arasında sayılmaktadır]) şeklinde ikiye ayrılarak incelenmektedir (TEPAV, 2006:25-31).

Yolsuzluğun nedenleri; ekonomik, sosyal, siyasal ve yönetsel nedenler olarak sınıflandırılabilmektedir. Ekonomik nedenler olarak kamu çalışanlarının ücret düzeyleri, gelir dağılımında adaletsizlik, enflasyon, devletin ekonomideki rolü, kayıt dışı ekonomi, siyasetin finansmanı; sosyal nedenler olarak eğitim eksikliği, vatandaşlık bilincinin yeterince oluşmamış olması, sınıflaşma eğilimi, sivil toplum örgütlenmesinin ve iş olanaklarının yetersizliği; siyasal nedenler olarak liyakat ilkesinin çiğnenmesi, popülist politikalar, idari yapının zayıflı̆̆ı; yönetsel nedenler olarak hesap verilebilirlik ve şeffaflığın olmaması, yetersiz idari ve mali sistemler, mesleki ahlak kurallarının yeterince tanımlanmaması, kamu tekelleri ve memurların takdir yetkisi, adli sistemden kaynaklanan nedenler (hukuk devletinin oturmamış olması, kamusal denetimin yetersizliği, afların sıklığı) olarak karşımıza çıkmaktadır (Korkmaz, Erkal, Minibaş, Baloğlu, Yılmaz, Çak, 2001:29-78; TEPAV, 2006:49-73).

\section{Yolsuzluk ve Sosyoekonomik Gelişmişlik ilişkisi}

Bir ülkede yolsuzluk faaliyetlerinin gerçekleşmesi; ülkenin ekonomik, sosyal, siyasi ve kültürel yapısına bağıı olarak ortaya çıkan birçok farklı unsura göre değişiklik göstermekte ve sosyal yapının giderek bozulmasına neden olmaktadır. Ülkelerin yolsuzluk faaliyetlerinin düşük veya yüksek düzeyde olduğunun belirlenmesi diğer bir ifadeyle yolsuzluğun ölçülmesi yolsuzluk endeksi ile mümkün olmaktadır.

Yolsuzlukların ölçülmesi konusunda çeşitli kurumların belirlediği endeksler bulunmaktadır. Bunlar; Business International Yolsuzluk Endeksi (BI), Global Rekabet Endeksi (GCS, 1997), Rüşvet Verme Endeksi (BPI), Uluslararası Ülke Risk Danışmanlığı Endeksi (ICRG), Opasite (Şeffaf Olmama) Endeksi (OPIN), Kaufmann, Kraay, ZoidoLobaton Endeksleri (KKZ) ve Uluslararası Şeffaflık Örgütü Yolsuzluk Endeksi (CPI)'dır. Bu endekslerden en yaygın olarak kullanılan endeks, Uluslararası Şeffaflık Örgütünün Yolsuzluk Algılama Endeksi'dir. Uluslararası Şeffaflık Örgütü tarafından belirlenen yolsuzluk algılama endeksi, yıllar itibariyle daha fazla ülkeyi analiz ederek ülkelerin yolsuzluk dereceleri hakkında bilgi vermektedir. Örneğin; 2000 yılında 90 ülke analiz edilmekteyken, 2017 yılında analiz kapsamına alınan ülke sayısı 180 olmaktadır. Bu durum, yolsuzluk derecelerinin dünya genelinde karşılaştırılmasını sağlamaktadır. Yolsuzluk algı endeksi ile ülkelere 0 ile 100 arasında bir puan verilmektedir. Yolsuzluk algı endeksinin 100 'e yakın olması yolsuzluğun düşük, 0'a yakın olması ise yolsuzluğun yüksek olduğunu göstermektedir.

Uluslararası Şeffaflık Örgütü tarafından dünyada yolsuzluk dereceleri bölgeler ve coğrafi sınıflandırmalar itibariyle aşağıda gösterilmektedir. Buna göre kırmızı ile gösterilen kısımlar yolsuzluğun en yüksek, sarı ile gösterilen kısımlar ise yolsuzluğun en düşük olarak gerçekleştiği bölgeler/ülkelerdir. 
Şekil 1. Dünyada Yolsuzluk Dereceleri (2017)

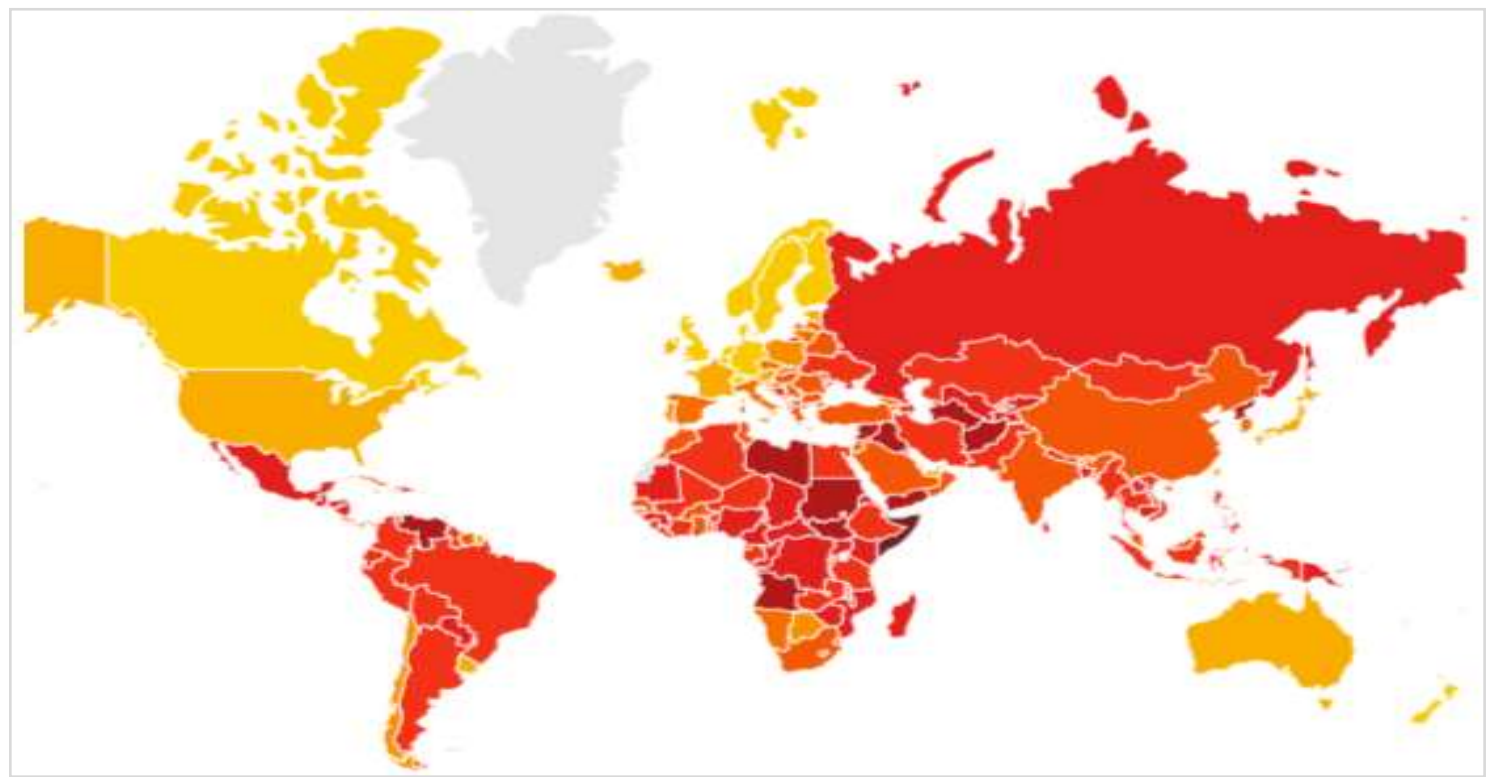

Kaynak: Transparency International, www.transparency.org.

Dünya genelinde bakıldığında yolsuzluk algı endeksi ortalaması 2017 yılı için 43 olarak gerçekleşmektedir (Transparency Internetional, 2018:6). Bölgesel olarak yolsuzluğun en az olduğu bölge 66 puan ile Avrupa Birliği ve Batı Avrupa bölgesi iken, en yüksek gerçekleştiği bölge ise 32 puan ile Sahra Altı Afrika bölgesidir (Transparency Internetional, 2018:6).

Dünyadaki yolsuzluk derecelerinde ülkelerin aldıkları puanlarda ekonomik durumlarının yanı sıra sosyal ve kültürel özellikleri de etkili olmaktadır. Zira yolsuzluk düzeylerine ilişkin karşılaştırma yapılırken, ülkelerin kültürel ve ahlaki özelliklerinin de dikkate alınması gerekmektedir (Fisman \& Miguel, 2011:90). Her ülkenin kurallara uyma kültürü ve hukuki düzenlemeleri farklı olup yolsuzluk algılama endeksleri değerlendirilirken bu durum göz önünde bulundurulmalıdır (Fisman \& Miguel, 2011:90).

Belirtilen nedenlerle yolsuzluk algı endeksi incelenirken, ülkelerin sosyal ve ekonomik gelişmişlik düzeylerinin ve böylece sosyoekonomik yapılarının incelenmesinin yarar sağlayacağı düşünülmektedir. Bu çerçevede genel bir karşılaştırma yapabilmek adına Tablo 1'de, 2015 yılı yolsuzluk algı endeksi sıralamasında en yüksek ve en düşük değerlere sahip olan 15 ülke ve bu ülkelerin sosyal ve ekonomik gelişmişlik düzeyleri yer almaktadır. Burada sosyal gelişmişlik göstergesi olarak insani gelişmişlik endeksi (human development index) ele alınmış olup UNDP tarafından sağlık, eğitim ve yaşam standardı olmak üzere üç farklı ölçüte dayanılarak geliştirilmiştir. Sağlık boyutu, ortalama yaşam süresi ile; eğitim boyutu, 25 yaş ve üzeri yetişkinler için ortalama eğitim süresi, okul çağına gelen çocuklar için beklenen eğitim süresi ortalaması ile; yaşam standardı boyutu ise kişi başına düşen milli gelir ile ölçülmektedir. Endeks, bu ölçütlerin ortalama değerinin alınmasıyla elde 
edilmektedir. Ekonomik gelişmişliğin karşılaştırılması için ise Legatum Institute tarafından oluşturulan ekonomik gelişmişlik endeksi alınmıştır.

Tabloda yolsuzluk algı endeksi YAE, insani gelişmişlik endeksi IGE ve ekonomik gelişmişlik endeksi EGE olarak ifade edilmiştir. Endekslerde ülkelere verilen puanlar 0 ile 100 arasında değişmekte; puanlar 0'dan 100'e doğru gidildikçe yolsuzluk düzeyi azalmakta, insani gelişmişlik ile ekonomik gelişmişlik ise artmaktadır. Karşılaştırma yapabilmek adına ilk olarak yolsuzluğun en düşük olduğu (en yüksek yolsuzluk algı endeksi puanına sahip olan-yolsuzluk açısından en temiz olan) ülkelerin endeksleri ele alınmış ve sonrasında yolsuzluk endeksinin en yüksek olduğu (en düşük yolsuzluk endeksi puanına sahip olan) ülkeler sıralandırılmış, tablonun en altında ise Türkiye'nin değerlerine yer verilmiştir.

Tablo incelendiğinde 2015 yılında yolsuzluğun en düşük olduğu (en yüksek yolsuzluk endeksine sahip) ülkelerin İskandinavya ülkeleri olduğu dikkat çekmekle birlikte, yine üst sıralarda bazı AB ülkeleri, Yeni Zelanda, Singapur, ABD, Japonya gibi gelişmiş ülkeler kategorisinde yer alan bazı ülkeler bulunmaktadır. Yolsuzluğun en yüksek olduğu (en düşük yolsuzluk endeksine sahip) ülkeler ise genellikle gelişmemiş veya az gelişmiş olarak nitelendirilen Afrika ülkeleri olmaktadır. Türkiye ise bu sıralamada 42 puan ile 66. sırada yer almaktadır.

Tablo 1. Yolsuzluğun En Yüksek ve En Düşük Olduğu 15 Ülke ve Türkiye'nin Yolsuzluk, İnsani Gelişmişlik ve Ekonomik Gelişmişlik Endeksleri (2015)

\begin{tabular}{|c|l|c|c|c|l|c|c|c|}
\hline SIra & \multicolumn{1}{|c|}{ Ülkeler } & YAE & IGE & EGE & Ülkeler & YAE & IGE & EGE \\
\hline $\mathbf{1}$ & Danimarka & 91 & 92 & 79 & Afganistan & 11 & 47 & 50 \\
\hline $\mathbf{2}$ & Finlandiya & 90 & 89 & 77 & Sudan & 12 & 49 & 45 \\
\hline $\mathbf{3}$ & İsveç & 89 & 91 & 80 & Angola & 15 & 53 & 45 \\
\hline $\mathbf{4}$ & Yeni & 88 & 91 & 81 & Libya & 16 & 71 & 45 \\
\hline $\mathbf{5}$ & Hollanda & 87 & 92 & 80 & Irak & 16 & 64 & 45 \\
\hline $\mathbf{6}$ & Norveç & 87 & 94 & 78 & Venezuela & 16 & 76 & 49 \\
\hline $\mathbf{7}$ & İsviçre & 86 & 93 & 79 & Yemen & 18 & 48 & 38 \\
\hline $\mathbf{8}$ & Singapur & 85 & 92 & 78 & Zimbabve & 21 & 51 & 57 \\
\hline $\mathbf{9}$ & Kanada & 83 & 92 & 77 & Comoros** & 24 & 49 & 48 \\
\hline $\mathbf{1 0}$ & Almanya & 81 & 92 & 79 & Uganda** & 25 & 49 & 61 \\
\hline $\mathbf{1 1}$ & Lüksemburg & 81 & 89 & 78 & Tacikistan** & 25 & 62 & 57 \\
\hline $\mathbf{1 2}$ & İngiltere & 81 & 90 & 78 & Nikaragua** & 26 & 64 & 59 \\
\hline $\mathbf{1 3}$ & Avustralya & 79 & 93 & 76 & Madagaskar** & 26 & 51 & 47 \\
\hline $\mathbf{1 4}$ & İzlanda & 79 & 92 & 74 & Kenya** & 26 & 55 & 57 \\
\hline $\mathbf{1 5}$ & Belçika & 77 & 89 & 76 & Kamerun** & 26 & 51 & 55 \\
\hline & TÜRKiYE & $\mathbf{4 2}$ & $\mathbf{7 6}$ & $\mathbf{6 6}$ & & & & \\
\hline
\end{tabular}

* Insani gelişmişlik endeksi verileri en son 2015 yılı için yayınlandığından, karşılaştırmada bütünlük sağlaması amacıyla tüm veriler 2015 yılı verileri olarak ele alınmıştır.

** Yolsuzluk algı endeksinde kendisinden daha düşük puan alan ülkelerin insani gelişmişlik ve/veya ekonomik gelişmişlik endekslerinde veri elde etme bakımından eksiklikler bulunduğu için sıralamada bu ülkeler kullanılmıştır. 
Kaynak: Yolsuzluk verileri Transparency internetional, 2016:6-7; İnsani gelişmişlik endeksi UNDP, 2016:198-201; ekonomik gelişmişlik endeksi Legatum Institute, 2015:3-4 verilerinden yararlanılarak tarafımızca oluşturulmuştur.

İnsani gelişmişlik ve ekonomik gelişmişlik açısından ele alındığında; yolsuzluk endeksi sıralamasında en iyi puan alarak en üst sıralarda yer alan ülkelerin sosyoekonomik gelişmişlik açısından da en üst sıralarda yer aldıkları dikkat çekmektedir. Özellikle eğitim düzeyi, yaşam kalitesi, ortalama yaşam süresi ve kişi başına düşen milli gelir ölçütlerini esas alarak oluşturulan insani gelişmişlik endeksi, ülkelerin sosyokültürel yapısını ve bu anlamda gelişmişlik düzeyini gösterdiğinden; ekonomik gelişmişlik düzeyi ile birlikte, yolsuzluk endeksini doğrudan etkileyen en önemli unsurlar olarak değerlendirilmektedir. Nitekim bu endeksler dikkatle incelendiğinde de yolsuzluk endeksi ile doğru orantılı olarak değiştiği gözlemlenebilmektedir.

\section{Literatür}

Çalışmada yolsuzluk ile ülkelerin sosyal ve ekonomik yapısı arasındaki ilişki; yolsuzluk ile ekonomik gelişmişlik, yönetişim, eğitim, politik istikrar ve sosyal sermaye değişkenleri arasındaki ilişki ele alınarak incelenmeye çalışılacaktır. Bu değişkenlerin yolsuzluk üzerindeki etkileri literatürde birçok çalışmada ayrı ayrı ele alınmıştır. Bu çalışmadaki farklılığı ise bu beş değişkenin yolsuzluk üzerindeki etkilerinin toplu olarak değerlendirilmesi oluşturacaktır.

Yolsuzluk ile ekonomik gelişmişlik üzerine yapılan çalışmalar değerlendirildiğinde; literatürde yolsuzluğun ekonomik gelişmişlik düzeyini olumsuz etkileyen, ekonomik gelişmeyi, büyümeyi ve kalkınmayı yavaşlatan bir unsur olduğunu belirten çalışmalar bulunmaktadır (Shabbir \& Anwar, 2007; Türedi \& Altıner, 2016). Mauro (1995) ise çalışmasında, yüksek düzeydeki bir yolsuzluğun ekonomik kalkınmaya yabancı yatırımları engelleyerek de zarar verdiğini savunmaktadır. Yalnızca yolsuzluk ekonomik gelişmişlik düzeyini etkilememekte, ekonomik gelişmişlik düzeyi de yolsuzluğun seviyesini değiştirmektedir. Öyle ki bir ülkenin ekonomik kalkınma düzeyinin yolsuzluğu etkilediği yönünde yapılan çalışmalar da bulunmaktadır (Alam, 1995; Macrae, 1982). Bu çalışmalarda düşük ekonomik kalkınma seviyesine sahip ülkelerde yolsuzluk faaliyetlerinin daha fazla olduğu sonucuna ulaşılmıştır. Literatürde bu çalışmaların aksine yolsuzluğun ekonomik gelişmeyi hızlandıracağı yönünde görüşler de bulunmaktadır. Bu çalışmalarda özellikle gelişmekte olan ülkelerde yolsuzluğun yatırımları ve ekonomik gelişmeyi artıracağı savunulmaktadır (Leff, 1964; Huntington, 1968). Ancak bu tür çalışmalara daha az rastlanmakla birlikte; yolsuzluğun ülkelerin vergi gelirlerinde azalmaya neden olması ve toplumdaki adalet, eşitlik ve güven algılarını zedelemesi nedeniyle ekonomi üzerinde olumsuz etki oluşturacağı düşünülmektedir. Literatürde yolsuzlukla ekonomik gelişme arasında pozitif ilişki olduğunu belirten bu görüşler çalışmamıza destek verir niteliktedir. 
Yolsuzluğu etkileyen bir diğer unsur, yönetişim kavramıdır. Yönetişim; bürokratik kalite, hukukun üstünlüğü, çok seslilik, hesap verebilirlik ve hükümet etkililiği değişkenlerinden oluşmaktadır (Güney, 2015:350). Bu değişkenlerin her birini ayrı ayrı incelediğimizde yolsuzlukla ilişkili olduklarını söylemek mümkündür. Yapılan çalışmalar bir ülkede yasal hukuk düzeni ve demokratik hesap verilebilirlik arttıkça yolsuzluk seviyesinin azaldığını göstermektedir (Brown \& Shackman, 2007). Tiwari (2012) yaptığı çalışmada, hukuk düzeninin yanı sıra yüksek demokrasinin olduğu ülkelerde yolsuzluğun daha az olduğunu belirtmektedir. Öyle ki uzun dönemler boyunca demokrasiye sahip olan ülkelerin daha düşük yolsuzluk derecesi elde ettiğini gösteren çalışmalar bu savı desteklemektedir (Treisman, 2000; Saha \& Su, 2012; Beşel \& Yardımcıoğlu, 2013). Bu çalışmalardan yola çıkarak demokrasi, hukukun üstünlüğü, hesap verilebilirlik, hükümetin etkinliği gibi birçok kavramın yolsuzluk düzeyini etkilediği söylenebilmektedir. Bu kavramların tümünü birlikte karşılayan tek kavram olması nedeniyle yönetişim değişkeni, çalışmada yapılacak olan analize dahil edilecektir. Çalışmada yönetişim değişkeni ile yolsuzluk arasında literatürü destekler şekilde pozitif bir ilişki beklenmektedir.

Yolsuzluğu etkileyen başka bir unsur ise eğitim seviyesidir (Sayan ve Kışlalı, 2004:5). Yapılan çalışmalar eğitim seviyesindeki artış ile yolsuzluk faaliyetleri arasında ters yönlü bir ilişkinin varlığından söz etmektedir (Zakaria, 2009; Ades \& Di Tella; 1997, Shaw, 2007). Eğitim seviyesi yüksek olan toplumlarda bireylerin yolsuzluk faaliyetlerinin olumsuz sonuçlarının farkındalığına sahip olmaları nedeniyle bu faaliyetlerden uzak kalmaları beklenmektedir. Dridi (2014) çalışmasında bu sonucu destekler bir şekilde, okullaşma oranı arttıkça yolsuzluk faaliyetlerinin azaldığını belirtmektedir. Nitekim Algan vd. (2014)'nin eğitim seviyesi yükseldikçe yolsuzluk faaliyetlerinden hüküm giyenlerin sayısının azaldığını gösteren çalışması bu sonucun destekleyicisidir. Eğitimin yolsuzluk üzerindeki bu olumlu etkisi nedeniyle eğitim harcamalarının bütçe içerisindeki payının artırılması yolsuzluğu olumlu yönde etkileyebilecektir. Bu doğrultuda yapılan çalışmalar ise yolsuzlukla eğitim harcamaları arasında ters yönlü bir ilişkinin varlığını ortaya koymuştur (Mauro, 1998; Delavallade, 2006; Erkan \& Kara, 2011). Yapılan bu çalışmalarda, yolsuzluk faaliyetlerinin eğitim harcamalarında azalışa neden olduğu tespit edilmiştir. Eğitimin insan üzerindeki olumlu katkısı nedeniyle çalışmamızda, literatürdeki eğitim ile yolsuzluk arasındaki ilişkiyi negatif bulan çalışmalar doğrultusunda sonuçlar elde edilmesi beklenmektedir.

Politik istikrar veya istikrarsızlık da yolsuzluk faaliyetlerinin belirleyicilerinden biri olmaktadır. Literatürde bir ülkede politik istikrarın varlığının yolsuzluk faaliyetlerinin daha az olmasını sağladığı yönünde çalışmalar mevcuttur (Park, 2003; Mbaku \& Paul, 1989; Treisman, 2000; Erkal, Akıncı, Yılmaz, 2015; Türedi \& Altıner, 2016; Pelligrini \& Gerlah 2008). Politik istikrardan yoksun olan bir ülkede kaos, kargaşa ve yolsuzluk faaliyetlerinin daha fazla görülmesi olasıdır. Öyle ki literatürde politik istikrarsızlığın sorun olduğu yerde yolsuzluk faaliyetlerinin daha yüksek oranda gerçekleştiği yönünde çalışmalar bulunmaktadır (Serra, 2006; Abu, Karim, Aziz, 2014). Benzer bir şekilde, Habib \& Zurawicki (2001) de çalışmalarında bir ülkenin şeffaflık ve siyasi istikrar derecesinin yüksekliğinin yolsuzluğu azalttığını belirtmektedir. 
Yolsuzluğu etkileyen bir diğer unsur da sosyal sermayedir. Sosyal sermaye, Dünya Bankası tarafından "insanların hedefleri gerçekleştirmek için harekete geçmesini sağlayan toplumsal yapıları oluşturan normlar ve sosyal ilişkiler" olarak tanımlanmaktadır (Cohen \& Prusak, 2001:2). Toplum kesimlerinin ve bireylerin birbirlerine olan güven düzeyi, yazılı olan ve olmayan her türlü toplumsal davranış ve kurallardan oluşan normlar ve sosyal içerikli iletişim imkanlarının niteliği, sosyal sermayenin genel düzeyini belirlemektedir (Kangal, 2013:7). Sosyal sermayenin yüksek seviyelerde olduğu bir toplumda rüşvet almaların ve yolsuzlukların azalma eğilimi göstermesi beklenmektedir. Bjornskov (2003) çalışmasında sosyal sermayenin yüksekliğinin yolsuzluğu azalttığını, yolsuzluğun azalmasının ise dış yatırımları cazip hale getirerek ekonomik büyümeyi artırdığını belirtmektedir. Dolayısıyla; Pozega vd. (2011)'in çalışmalarında belirttiği gibi, bir ülkede sosyal sermayenin artışı ekonomik gelişmeyi artırarak yolsuzluğun azalmasına katkıda bulunmaktadır.

Mevcut literatürde yolsuzluk değişkeni üzerindeki ekonomik gelişmişlik, yönetişim, eğitim düzeyi, politik istikrar ve sosyal sermaye değişkenlerinin etkileri ayrı ayrı incelenmiş ancak bu beş değişkenin aynı anda yolsuzluk üzerine etkileri analiz edilmemiştir. Bu çalışmayla birlikte ekonomik gelişmişlik, yönetişim, eğitim düzeyi, politik istikrar ve sosyal sermaye değişkenlerinin yolsuzluk üzerine etkisinin araştırımasının literatüre katkı sağlayacağı ve çalışmanın özgün değerini oluşturacağı düşünülmektedir.

\section{Analiz}

\subsection{Panel Veri Analizi}

Ekonometrik çalışmalarda birçok farklı veri türü kullanılmakta olup bu veri türleri için uygun olan yöntemler farklılık göstermektedir. Analizlerde; zaman serisi verisi, yatay kesit verisi ve panel veri olmak üzere üç çeşit veri kullanılmaktadır. Zaman serisi verisi, değişkenlerin gün, ay, mevsim, yıl gibi zaman birimlerine göre değişimini içeren verilere; yatay kesit veri, zamanın belli bir noktasında farklı birimlerden toplanan verilere denilmekteyken; panel veri ise bireyler, ülkeler, firmalar, hane halkları gibi birimlere ait yatay kesit gözlemlerin, belli bir dönemde bir araya getirilmesi olarak tanımlanmaktadır (Yerdelen Tatoğlu, 2016:1-2).

Panel veri analizinde tahmin yöntemi olarak kullanılabilecek olan yöntemler; klasik model (havuzlanmış en küçük kareler-pooled ordinary least square (pooled OLS)), sabit etkiler modeli ve tesadüfi (rassal) etkiler modelidir. Bütün gözlemlerin homojen olduğu diğer bir ifadeyle birim ve/veya zaman etkilerinin olmadığı düşünülüyorsa klasik modelin, birim ve/veya zaman etkilerinin olduğu düşünülüyorsa sabit ya da tesadüfi etkiler modellerinin kullanılması daha mantıklı olup bu iki model arasındaki seçim ise modelin tahmin edilmesindeki amaca bağlı olarak yapılabilmektedir (Yaşar, 2016:69). Bu modeller arasındaki seçim ise f testi, Hausman testi ve Olabilirlik Oranı (LR) testi olarak adlandırılan spesifikasyon testlerinin uygulanmasıyla yapılmaktadır. 


\subsection{Değişkenler ve Veri Seti}

Çalışmada; zaman serisi boyutu, on yıllık (2007-2016) bir zaman dilimini kapsayacak şekilde oluşturulurken, yatay kesit boyutu olarak toplam 120 ülke verisinden yararlanılmıştır. Çalışmada hem yatay kesit hem de zaman boyutu olduğu için seçilen yöntem, panel veri analizi olmuş ve analiz için Stata programı kullanılmıştır. Çalışmada biri bağımlı, beşi bağımsız olmak üzere toplam altı değişken kullanılmış olup tüm veriler yüzdesel oran şeklinde ele alınmıştır. Çalışmada kullanılan veriler Transparency International (Uluslararası Şeffaflık Örgütü), Legatum Institute ve Dünya Bankası verilerinden elde edilmiştir.

$\mathrm{t}$ dönemi ve i ülke boyutunu göstermek üzere yolsuzluk algı endeksi Transparency International verilerinden elde edilmiş olup bağımlı değişken olarak çalışmaya dahil edilmiştir. Çalışmaya dahil edilmesi düşünülen değişkenlerden devletin etkinliği, hukuk kurallarının uygulanabilirliği, insani gelişmişlik endeksi ve iş ortamı değişkenleri; çoklu doğrusal bağlantı sorununa neden olduğundan analizden çıkarılmıştır. Bu bağlamda analizde kullanılacak olan bağımsız değişkenler şu şekilde belirlenmiş olup değişkenlere ait tanımlayıcı istatistiklere ilişkin detaylı bilgi aşağıda gösterilmektedir.

Tablo 2. Değişkenlere Ait Tanımlayıcı İstatistikler

\begin{tabular}{|c|c|c|c|c|c|}
\hline Değişken & Gözlem & Ortalama & Stand. Hata & Min & Mak \\
\hline \multicolumn{5}{|c|}{ Düşük gelirli ülkeler } \\
\hline yol & 150 & 29.47 & 7.62 & 16 & 54 \\
eg & 150 & 53.25 & 5.83 & 43.58 & 66.34 \\
yon & 150 & 40.58 & 8.08 & 18.92 & 54.46 \\
egit & 150 & 34.10 & 7.88 & 16.40 & 51.85 \\
ss & 150 & 44.79 & 5.06 & 32.68 & 54.46 \\
pol & 150 & 28.15 & 16.74 & 3.79 & 66.82 \\
\hline \multicolumn{5}{|c|}{ Orta gelirli ülkeler } \\
\hline yol & 650 & 33.96 & 9.12 & 17 & 65 \\
eg & 650 & 59.50 & 5.75 & 42.30 & 73.84 \\
yon & 650 & 45.25 & 8.71 & 24.14 & 69.05 \\
egit & 650 & 54.64 & 7.92 & 26.46 & 70.24 \\
ss & 650 & 48.17 & 5.54 & 34.88 & 62.31 \\
pol & 650 & 4.19 & 19.91 & 0.47 & 92.78 \\
\hline \multicolumn{5}{|c|}{ Yüksek gelirli ülkeler } \\
\hline yol & 400 & 69.26 & 16.43 & 32 & 95 \\
eg & 400 & 73.55 & 6.03 & 58.50 & 84.41 \\
yon & 400 & 68.22 & 11.39 & 37.03 & 86.28 \\
egit & 400 & 69.98 & 8.13 & 52.13 & 82.43 \\
ss & 400 & 56.60 & 7.15 & 36.20 & 68.95 \\
pol & 400 & 74.86 & 16.25 & 27.61 & 100 \\
\hline
\end{tabular}


Aşağıda ise değişkenlere ilişkin detaylı bilgi, alt değişkenler ile birlikte yer almaktadır:

- $\mathrm{X} 1$ it = egit: Ekonomik gelişmişlik endeksi, Legatum Institute tarafından oluşturulan endekslerden biri olup endeksin oluşturulmasında; yaşam standartları (yaşam standartlarından memnuniyet, hane halkının gelir düzeyinden memnuniyeti, beş yıllık ekonomik büyüme oranı), ekonominin kapsamlılı̆̆ (herkesin toplumda yer almasını sağlayacak kaynak ve olanaklara sahip olma derecesi) (günde 1,90 doların altında yaşayan nüfus-mutlak yoksulluk, göreceli yoksulluk, bir banka hesabına sahip yetişkin nüfus yüzdesi), tekelleşmeyi önleyici politikalar (üreticilerin piyasada serbest rekabet ortamına sahip olup olmadıkları ve tüketicilerin neyi satın alacakları konusunda seçim yapıp yapamayacakları), iş gücüne katılım oranı (15 yaş ve üzeri iş gücüne katılım oranı, 15 yaş ve üzeri kadınların iş gücüne katılım oranı, işsizlik oranı), ticarette rekabet edilebilirlik düzeyi (ihracat çeşitliliği endeksi, ihracat kalite endeksi) ve ticari dışa açıklık (ticarete yönelik tarife dışı engellerle ilgili algılamalar) gibi hususlar dikkate alınmaktadır (Legatum Institute, 2017:48).

- X2it = yonit $: \mathrm{t}$ döneminde $\mathrm{i}$ ülkesindeki yönetişim düzeyini göstermekte olup Legatum Institute tarafından oluşturulan endekslerdendir. Yönetişim endeksi oluşturulurken; hukukun üstünlüğü (toplumun hukuk kurallarına olan güveni, sözleşmelerin uygulanması, mülkiyet hakları, polis ve mahkemelere ilişkin işlemlerde herkese eşit davranılması, Dünya Bankası hukuk kuralları endeksi, yargının bağımsızlığı), hükümetin güvenilirliği (hükümetin en az yolsuzlukla ne kadar şeffaf ve öngörülebilir bir şekilde faaliyet gösterdiği, hükümetin politika değişikliklerinin şeffaflığına ilişkin algılar, kamu kesimi yolsuzluğu), hükümetin performansı (sivil hizmetin performansı, regülasyonların ve politikaların işletmeleri ne derecede teşvik ettiği, hükümetin iyi bir politika oluşturup uygulayabilme yeteneğine ilişkin algılar, kamu hizmetlerinin ve sivil hizmetlerin kalitesi ve bağımsızlığı, vatandaşların hükümete olan güveni) ve politik katılım (tüm vatandaşların siyasi sürece aktif katılımlarının olup olmadığı, seçimlerin dürüst bir biçimde yapıldığına dair vatandaşların algısı, ulusal parlamentoda kadın temsilci yüzdesi) gibi unsurlar göz önünde bulundurulmaktadır (Legatum Institute, 2017:50).

- $\mathrm{X} 3$ it = egitit: Eğitim endeksi, $\mathrm{t}$ döneminde $\mathrm{i}$ ülkesindeki eğitim düzeyini göstermekte olup Legatum Institute verilerinden alınmıştır. Endeks oluşturulurken; eğitime erişim (eğitim hizmetlerinin kapsamının genişliği ve erişilebilir olması, yetişkin ve genç okur yazar oranı, kızların erkeklere göre okula kaydolma oranı, eğitim hizmetlerinin dağılımında Gini katsayısı), eğitimin kalitesi (çocukların öğrenme düzeyine ilişkin vatandaşların algısı, ilk ve orta derecede eğitimin kalitesi, ilkokulu tamamlama düzeyi, yerel okullardan memnuniyet derecesi, en iyi üniversitelerin sayısı, üniversitelerin uluslararası itibarı) ve iş gücünün beşeri sermayesi (araştırma ve gelişmeyi teşvik eden iş gücündeki beceriler, işçi başına orta öğretim yılı, işçi başına 
yüksek öğrenim düzeyi, teknik/mesleki eğitimde kayıtlı orta öğretim öğrencilerinin oranı) unsurları dikkate alınmaktadır (Legatum Institute, 2017:54).

- X4it = polit $: \mathrm{t}$ döneminde $\mathrm{i}$ ülkesinde terörizm de dahil olmak üzere ülkedeki şiddet eğilimini ve politik istikrar düzeyini temsil etmektedir. Worldwide Governance Indicators arasında yer alan politik istikrar verileri, Dünya Bankası resmi sitesinden alınarak hazırlanmıştır. Politik istikrar endeksinin oluşturulmasında; devletin istikrar düzeyi, ülkedeki iç ve dış çatışmaların yoğunluğu, ülke içi etnik, dini ve bölgesel çatışmalar, terörizm ve terörizmin neden olduğu maliyetler, uluslararası gerilim/terör tehdidi, güvenlik risk düzeyi, protesto ve isyanların niteliği (iş̧̧iler ile ilgili olanlar hariç), eyaletler arası savaş, silahlı çatışmalar ve şiddet içeren gösteriler yapılması, sosyal çatışmaların yoğunluğu (toprak ile ilgili olanlar hariç), iç savaş riski gibi değişkenler dikkate alınmaktadır.

- X5it = ssit : Sosyal sermaye endeksi, Legatum Institute tarafından oluşturulan bir endekstir. Bir ülkede yaşayan insanların birbirleriyle olan etkileşimleri, birbirlerine güven ve saygı duymaları ve sosyal çevreleri tarafından desteklenmeleri, ülkedeki refah düzeyini ve dolayısıyla ekonomik büyümeyi doğrudan artıran bir olgu olarak değerlendirilmekte ve sosyal sermaye endeksinin önemi de burada ortaya çıkmaktadır (Legatum Institute, 2017:52).

Sosyal sermaye endeksi oluşturulurken hesaba katılan değişkenler ise kişisel ve sosyal ilişkiler (arkadaş edinme olanaklarına ilişkin algılar, aile veya arkadaşlardan yardım bekleme düzeyi, yabancılara yardım etme sıklığı, kayıt dışı mali yardım yapma sıklığı), sosyal normlar (sosyal uyum, sosyal bağlılık, polis vb. kurumlara duyulan güven duygusu, insanların birbirlerine davranış biçimi, güven duygusu ve saygı düzeyi) ve sivil katılım (hayır kurumlarına yapılan bağışlar, gönüllülük düzeyi, kamu görevlisine görüş bildirme sıklığı, seçmen katılımı) dır (Legatum Institute, 2017:52).

Belirtilen değişkenler çerçevesinde analizde uygulanacak model şu şekilde belirlenmiştir:

$$
\text { yolit }=60+61 \text { egit }+62 \text { yonit }+ \text { b3egitit }+64 \text { polit }+65 s s i t+u i t
$$

\subsection{Model}

Oluşturulan model çerçevesinde değişkenlerin yolsuzluk üzerindeki etkilerini ölçmede analize dahil edilen 120 ülkeye ait veriler, daha etkin sonuçlar elde edilebilmesi amacıyla bu ülkelere ilişkin olarak yapılan sınıflandırma ile analiz edilmiştir. Bu bağlamda, ülke sınıflandırması aşamasında Dünya Bankası tarafından ülkelerin gelir düzeylerine göre düşük gelirli, orta gelirli ve yüksek gelirli ülkeler olmak üzere üç gruba ayrılarak yapılan sınıflandırma esas alınmıştır. 
Dünya Bankası sınıflandırmasına göre 2016 yılı rakamlarına göre kişi başına düşen gayri safi milli hasıla bazında 1.005 dolar ve altı düşük gelirli ülke, 1.006-3.955 dolar arasında orta düşük gelirli ülke, 3.956-12.235 dolar arasında yüksek orta gelirli ülke ve 12.236 dolar üzeri yüksek gelirli ülke olarak tanımlanmaktadır. Ayrıca ülke sınıflandırmalarında 31 düşük gelirli ülke, 109 orta gelirli ülke ve 78 yüksek gelirli ülke olmasına rağmen; verilerin tüm ülkeler için elde edilememesi nedeniyle analizde 15

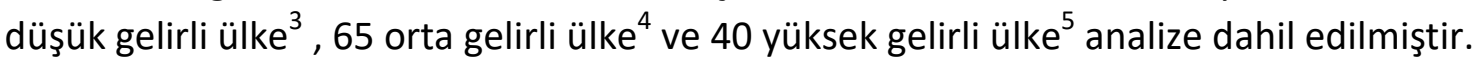

Analizde uygulanacak olan modelin seçimi için tüm ülke grupları itibariyle ve ayrıca birim ve zaman etkilerinin varlığını da sınamak amacıyla bazı testler uygulanmıştır. Klasik model ile sabit etkiler modeli arasında tercih yapmak için $f$ testi (bütün birim veya zaman etkilerinin sıfıra eşit olduğu HO hipotezi sınanmaktadır), sabit etkiler modeli ile tesadüfi etkiler modeli arasında tercih yapmak için Hausman testi (HO hipotezi tesadüfi etkiler modeli uygundur şeklinde kurulmaktadır) ve Olabilirlik Oranı (LR) testi (HO hipotezi klasik model doğrudur şeklinde kurulmaktadır).

Yapılan analizler sonucunda düşük gelirli ve orta gelirli ülke grupları için iki yönlü sabit etkiler, yüksek gelirli ülke grubu için ise tek yönlü sabit etkiler modelinin uygulanması gerektiği tespit edilmiş ve sabit etkiler modeli için analiz yöntemi olarak gruplar içi tahmin yöntemi uygulanmıştır.

Modellerde değişen varyans, otokorelasyon veya birimler arası korelasyondan en az biri varsa, ya parametre tahminlerine dokunmadan standart hatalar düzeltilmeli (dirençli standart hatalar elde edilmeli) ya da varlıkları halinde uygun yöntemlerle tahminler yapılmalıdır (Yerdelen Tatoğlu, 2016:251-252). Bu bağlamda, bu üç durumun varlığını sınamak için yapılan testler sonucunda elde edilen bulgular Tablo 3.'te yer almaktadır.

Cite this article as: Buz, F. \& Erul M.R. (2018). "Sosyoekonomik Gelişmişlik Düzeyinin Yolsuzluk Alg। Endeksi Üzerindeki Etkisine İlişkin Bir Analiz", International Journal of Public Finance, Vol.3, No.2, pp. 233-248.

\footnotetext{
${ }^{3}$ Benin, Burkina Faso, Burundi, Çad, Etiyopya, Madagaskar, Malavi, Mali, Mozambik, Nepal, Ruanda, Senegal, Tanzanya, Uganda, Zimbabve.

${ }^{4}$ Arjantin, Arnavutluk, Azerbaycan, Bangladeş, Bolivya, Botsvana, Brezilya, Bulgaristan, Cezayir, Çin, Dominik Cumhuriyeti, Ekvador, El Salvador, Endonezya, Ermenistan, Filipinler, Gana, Guatemala, Guyana, Güney Afrika, Gürcistan, Hırvatistan, Hindistan, Honduras, İran, Jameyka, Kambodya, Kamerun, Karadağ, Kazakistan, Kenya, Kırgızistan, Kolombiya, Kosta Rika, Lebanon, Lesotho, Makedonya, Malezya, Moritanya, Mısır, Morityus, Meksika, Moldova, Mongolya, Morokko, Namibia, Nikaragua, Nijerya, Pakistan, Panama, Paraguay, Peru, Romanya, Rusya, Sırbistan, Sri Lanka, Tacikistan, Tayland, Türkiye, Tunus, Ukrayna, Ürdün, Venezuela, Vietnam.

${ }^{5}$ ABD, Almanya, Avustralya, Avusturya, Belçika, Birleşik Krallık, Çek Cumhuriyeti, Danimarka, Estonya, Finlandiya, Fransa, Hollanda, Hong Kong, İrlanda, İspanya, İsveç, İsviçre, İtalya, İzlanda, Japonya, Kanada, Katar, Kıbrıs, Letonya, Litvanya, Lüksemburg, Macaristan, Norveç, Polonya, Portekiz, Singapur, Slovakya, Slovenya, Suudi Arabistan, Şili, Trinidad ve Tobago, Umman, Uruguay, Yeni Zelanda, Yunanistan.
} 
Tablo 3. Değişen Varyans, Otokorelasyon ve Birimler Arası Korelasyonun Varlığının Sınanmasına ílişkin Sonuçlar

\begin{tabular}{|c|c|}
\hline \multicolumn{2}{|r|}{ Düşük Gelirli Ülkeler } \\
\hline Değişen varyans & $\begin{array}{l}\text { chi2 }(15)=388.28 \\
\text { Prob }>\text { chi2 }=0.0000\end{array}$ \\
\hline Otokorelasyon & $\begin{array}{c}\text { modified Bhargava et al. Durbin-Watson }=.72842794 \\
\text { Baltagi-Wu LBI }=.98624168\end{array}$ \\
\hline $\begin{array}{l}\text { Birimler arası } \\
\text { korelasyon }\end{array}$ & Pesaran's test of cross sectional independence $=5.680, \mathrm{Pr}=0.0000$ \\
\hline \multicolumn{2}{|l|}{ Orta Gelirli Ülkeler } \\
\hline Değişen varyans & $\begin{array}{l}\text { chi2 }(65)=717.88 \\
\text { Prob>chi2 }=0.0000\end{array}$ \\
\hline Otokorelasyon & $\begin{array}{c}\text { modified Bhargava et al. Durbin-Watson }=.87152664 \\
\text { Baltagi-Wu LBI }=1.0822329\end{array}$ \\
\hline $\begin{array}{l}\text { Birimler arası } \\
\text { korelasyon }\end{array}$ & $\begin{array}{l}\text { Pesaran's test of cross sectional independence }=47.142, \mathrm{Pr}= \\
0.0000\end{array}$ \\
\hline \multicolumn{2}{|c|}{ Yüksek Gelirli Ülkeler } \\
\hline Değişen varyans & $\begin{array}{l}\text { chi2 }(40)=770.57 \\
\text { Prob>chi } 2=0.0000\end{array}$ \\
\hline Otokorelasyon & $\begin{array}{c}\text { modified Bhargava et al. Durbin-Watson }=.74933484 \\
\text { Baltagi-Wu LBI }=1.0255315\end{array}$ \\
\hline $\begin{array}{l}\text { Birimler arası } \\
\text { korelasyon }\end{array}$ & $\begin{array}{l}\text { Pesaran's test of cross sectional independence }=0.662 \\
\qquad \operatorname{Pr}=0.5080\end{array}$ \\
\hline
\end{tabular}

Değişen varyansın sınanması için Değiştirilmiş Wald testi, otokorelasyonun sınanması için Bhargava, Franzini ve Narendranathan'ın Durbin Watson ve BaltagiWu'nun Yerel En İyi Değişmez testleri ve birimler arası korelasyonun sınanması için Pesaran'ın testi uygulanmıştır. Bu üç durumdan en az birinin varlığı tespit edildiğinden, dirençli tahminciler uygulanması gerektiği sonucuna ulaşılmıştır.

\subsection{Analiz Sonuçlarının Elde Edilmesi ve Değerlendirilmesi}

Literatürde dirençli tahmincilere ilişkin olarak pek çok yöntem önerilmekle birlikte, en yaygın olarak kullanılanlardan biri Beck-Katz (1995) tahmincisidir. Bu nedenle çalışmada dirençli tahminci yöntemi olarak Beck-Katz yöntemi uygulanmış olup değişen varyans, otokorelasyon ve birimler arası korelasyon sorununu dikkate alan nihai tahmin sonuçları aşağıda ülke grupları itibariyle ayrı ayrı gösterilmektedir. 
Buz, F. \& Erul M.R. (2018). “Sosyoekonomik Gelişmişlik Düzeyinin Yolsuzluk Algı Endeksi Üzerindeki Etkisine İlişkin Bir Analiz", International Journal of Public Finance, Vol.3, No.2, pp. 233-248.

Tablo 4. Değişen Varyans, Otokorelasyon ve Birimler Arası Korelasyonu Dikkate Alan Tahmin Sonuçları

\begin{tabular}{|l|c|c|c|}
\hline yol & Düşük Gelirli Ülkeler & Orta Gelirli Ülkeler & Yüksek Gelirli Ülkeler \\
\hline eg & -0.115 & 0.052 & $0.568^{* * *}$ \\
& $(0.459)$ & $(0.325)$ & $(0.005)$ \\
yon & $0.468^{* * *}$ & $0.685^{* * *}$ & $0.911^{* * *}$ \\
& $(0.000)$ & $(0.000)$ & $(0.000)$ \\
egit & 0.040 & $0.072^{*}$ & -0.054 \\
& $(0.737)$ & $(0.083)$ & $(0.591)$ \\
pol & -0.001 & $0.058^{* * *}$ & $0.085^{* *}$ \\
& $(0.982)$ & $(0.000)$ & $(0.011)$ \\
ss & 0.124 & -0.077 & $0.153^{*}$ \\
& $(0.259)$ & $(0.219)$ & $(0.065)$ \\
Sabit & 96196 & -24.158 & $-46.187^{* * *}$ \\
R & $(0.113)$ & $(0.524)$ & $0.000)$ \\
F stat & 0.5529 & 0.7155 & 0.9128 \\
\hline
\end{tabular}

Not: Parantez içi değerler, prob değerlerini belirtmekte olup $* * * * *$ ve * işareti sırasıyla $\% 1, \% 5$ ve \%10'da sıfır hipotezinin reddedildiğini göstermektedir.

Modelin açıklama gücü düşük gelirli ülkeler için \%55, orta gelirli ülkeler için \%71 ve yüksek gelirli ülkeler için \%91 düzeyinde bulunmuştur ki bu oranlar, panel veri modellerinde modelin açıklayıcılık gücünün oldukça yüksek bir düzeyde olduğunu göstermektedir. Modelde tahmin edilen katsayıların anlamlılık düzeyleri ise $\% 1, \% 5$ ve \%10 düzeylerinde değişmekte olup değişkenler genel olarak \%1 düzeyinde anlamlı bulunmuş, bazı değişkenler ise istatistiki olarak anlamsız bulunmuştur.

İlk olarak ekonomik gelişmişlik endeksinin yolsuzluk üzerindeki etkisi incelendiğinde, değişkenin yalnızca yüksek gelirli ülke grubu için anlamlı olduğu tespit edilmiştir. Buna göre, yolsuzluk değişkenindeki bir birimlik artış, yolsuzluk değişkeninde 0.568 birimlik artışı beraberinde getirmektedir. Bu bulgu, yüksek gelirli ülkelerde ekonomik gelişmişlik düzeyinde görülen artışın, yolsuzluk algı endeksi puanını artırarak daha düşük yolsuzluk düzeylerine sahip olmalarını sağladığı anlamına gelmektedir. Bu durum, yüksek ekonomik gelişmişlik seviyesine sahip ülkelerde hukuk düzeni işleyişinin ve kurallarının uygulanabilirlik derecesinin de yüksek olması, ekonomik faaliyetlerin gelişmişliği nedeniyle denetim oranlarının yüksekliği ve piyasaların gelişmiş olması ile ülke vatandaşlarının bilinç düzeyinin yüksek olması gibi unsurlara bağlanabilmektedir. Analizde elde edilen bu sonuç, literatürde kalkınma düzeyinin düşük olduğu ülkelerde yolsuzluk faaliyetlerinin de fazla olduğunu savunan çalışmaları destekler niteliktedir.

Yönetişim endeksinin, tüm değişkenler için anlamlı olması ve ilişki yönünün tüm ülkeler için beklendiği gibi elde edilmesi dolayısıyla çalışmanın en güçlü değişkeni olduğu ifade edilebilmektedir. Yönetişim endeksi ile yolsuzluk arasındaki ilişkiye bakıldığında tüm ülke grupları itibariyle yönetişimdeki 1 birimlik artışın yolsuzluk algı 
endeksini olumlu olarak etkilediği sonucuna ulaşılmıştır. Bu sonuç, yönetişimin kapsadığı unsurların ele alındığı çalışmalar incelendiğinde, literatür ile uyumlu olup burada dikkat çeken husus, düşük gelirli ülkelerden yüksek gelirli ülkelere doğru gelindikçe yönetişimin yolsuzluk üzerindeki olumlu etkisinin daha büyük olarak gerçekleşmesidir. Bu durum, yönetişim endeksini oluşturan demokratiklik düzeyi, hukuk kurallarının uygulanabilirliği, yolsuzlukla mücadele bağlamında vatandaşların devletin politikalarına olan güveni gibi unsurlar itibariyle bakıldığında, mevcut durum itibariyle en yüksek değerlere sahip olan ülkelerin yüksek gelirli ülkeler olmasından ileri gelmektedir. Nitekim yolsuzluk sıralamasında ilk sıraları paylaşan İsveç, Norveç, Danimarka, Finlandiya, Yeni Zelanda gibi ülkeler yüksek gelirli ülkeler arasında yer almakta olup yolsuzlukla mücadelede de uygulama açısından en etkin politikalara ve hukuk kurallarına sahip ülkeler olarak değerlendirilmektedir.

Eğitim düzeyinin ise politik istikrar ile birlikte, çalışmada kurulan modeller itibariyle yolsuzluk üzerinde en az etki oluşturan değişken olduğu tespit edilmiştir. Eğitim düzeyindeki artışın yolsuzluk algı endeksi üzerindeki etkisinin; düşük gelirli ülkelerde pozitif (yolsuzluk faaliyetlerinin azalması) ve istatistiki olarak anlamsız, orta gelirli ülkelerde pozitif ve anlamlı, yüksek gelirli ülkelerde negatif (yolsuzluk faaliyetlerinin artması) ve anlamsız olduğu görülmektedir. Değişkenin istatistiki olarak anlamlı bulunduğu orta gelirli ülkelerde, hali hazırda eğitim düzeyi yüksek gelirli ülkelere kıyasla düşük olduğundan, eğitim düzeyindeki artışın yolsuzluk üzerinde olumlu etki oluşturması beklenen sonuç olup literatürde yer alan sonuçlara uygun olduğu görülmektedir.

Politik istikrarın da eğitim düzeyinde olduğu gibi yolsuzluk üzerindeki etkisi tüm ülke grupları itibariyle çok yüksek düzeylerde olmayıp bu etki yalnızca düşük gelirli ülkeler için anlamsız bulunmuştur. Politik istikrar endeksindeki 1 birimlik artışın yolsuzluk algı endeksindeki etkisi; orta gelirli ülkelerde 0.058 birim pozitif, yüksek gelirli ülkelerde ise 0.085 birim pozitif olarak gerçekleşmekte olup bu sonuçların literatüre uygun olduğu görülmektedir. En önemli etki yüksek gelirli ülkelerde meydana gelmekte olup özellikle bu ülkeler çatışmaların, gerilimin ve terör tehdidinin en az düzeyde olduğu diğer bir ifadeyle politik istikrarın en yüksek olduğu ülkeler olduğundan kaos ve karmaşanın düşük olmasına bağlı olarak yolsuzluk faaliyetlerinin de düşük düzeyde olması beklenen sonuçtur.

Son olarak sosyal sermaye endeksi ile yolsuzluk arasındaki ilişkinin, yalnızca yüksek gelirli ülkeler için anlamlı olduğu tespit edilmiştir. Yüksek gelirli ülkeler için Mevcut literatürde yolsuzluk değişkeni üzerindeki ekonomik gelişmişlik, yönetişim, eğitim düzeyi, politik istikrar ve sosyal sermaye değişkenlerinin etkileri ayrı ayrı incelenmiş ancak bu beş değişkenin aynı anda yolsuzluk üzerine etkileri analiz edilmemiştir. Bu çalışmayla birlikte ekonomik gelişmişlik, yönetişim, eğitim düzeyi, politik istikrar ve sosyal sermaye değişkenlerinin yolsuzluk üzerine etkisinin araştırılmasının literatüre katkı sağlayacağı ve çalışmanın özgün değerini oluşturacağı düşünülmektedir. Sermaye artışının yolsuzluk faaliyetlerini azalttığı görüşüne uygun olduğu görülmektedir. Nitekim bireylerin sosyal ilişkileri güçlendikçe topluma aidiyet duyguları ve devlete güvenleri de artacağından, bu ülkelerde yolsuzluk faaliyetine 
eğilim de azalacaktır. Dolayısıyla sosyal sermayedeki artışın yolsuzluk algı endeksi üzerindeki pozitif etkisinin yüksek gelirli ülkelerde görece daha yüksek olmasının, bu ülkelerde devletin etkin yönetimi nedeniyle vatandaşların topluma ve devlete bağlılık duygularının da yüksek olmasından ileri geldiği düşünülmektedir.

\section{Sonuç}

Yolsuzluk olgusu, günümüzde birçok ülkenin karşı karşıya kaldığı önemli bir sorundur. Yolsuzluklar; rüşvet, zimmet, irtikap, rant kollama, lobicilik gibi birçok fiilin oluşumuyla ortaya çıkabilmekle birlikte esas itibariyle doğrudan cezai yaptırıma bağlanan yolsuzluklar ve dolaylı olarak cezai yaptırıma bağlanan veya suç sayılmayan yolsuzluklar şeklinde ikiye ayrılarak incelenmektedir.

Yolsuzluk; ekonomik, sosyal, siyasal ve yönetsel olmak üzere birçok nedenden kaynaklanarak ortaya çıkabilmektedir. Yapılan çalışmalarda, bu unsurları içeren birçok değişkenin yolsuzluk ile ilişkisi ölçülmüş olup literatürde konuya ilişkin farklı görüşler yer almaktadır. Nitekim bu çalışmalarda, yolsuzluk ile ilişkisi ortaya koyulmaya çalışılan değişkenlerin temelini sosyoekonomik yapının oluşturduğu düşünüldüğünden, sosyoekonomik yapıyı oluşturan unsurların yolsuzluk algı endeksi üzerindeki etkinin incelenmesi, çalışmanın temelini oluşturmaktadır.

Çalışmada, sosyoekonomik yapının yolsuzluk faaliyetleri üzerindeki etkisinin ölçülmesi bağlamında, bağımlı değişken olarak yolsuzluk algı endeksi; bağımsız değişkenler olarak ise sosyoekonomik yapıyı oluşturan ekonomik gelişmişlik, yönetişim, eğitim düzeyi, politik istikrar ve sosyal sermaye değişkenleri kullanılmıştır. Değişkenlere ait 120 ülke verisi Dünya Bankası sınıflandırması esas alınarak düşük, orta ve yüksek gelirli olmak üzere üç ülke grubu için, 2007-2016 dönemini kapsayacak şekilde panel veri analizi yöntemi ile analiz edilmiştir. Yapılan analiz sonucunda, yolsuzluk algı endeksi ile analize dahil edilen sosyoekonomik unsurlar arasında önemli düzeyde ilişki olduğu tespit edilmiştir. Bu nedenle ülkelerin yolsuzluğun önlenmesine yönelik politikalarının belirlenmesinde, sosyoekonomik yapıyı oluşturan unsurların esas alınması (örneğin, tüm ülke grupları için yönetişimin artması yolsuzluk algı endeksinin değerinin artmasını-yolsuzluğun azalmasını en güçlü değişken olarak sağladığından; yolsuzlukla mücadelede hukuk kurallarının uygulama ve yaptırım gücü, hükümetin güvenilirliği, politik katılım gibi unsurlara ağırlık verilmesi) gerektiği sonucuna ulaşılmıştır.

Yolsuzluğun önlenmesi konusunda ülkeler tek bir değişken üzerine yoğunlaşmak yerine sosyoekonomik yapıyı oluşturan değişkenleri bir bütün olarak ele alıp iyileştirmeye çalışmalıdırlar. Öyle ki yalnızca tek bir sosyoekonomik faktörde iyileşme sağlayıp diğer sosyoekonomik unsurları göz ardı ederek yolsuzluk üzerinde azaltıcı bir etkiye ulaşmak olası görülmemektedir. 


\section{Kaynakça}

Abu, N., Karim, M., Aziz, M. (2014). “Corruption, Political Instability and Economic Development in the Economic Community of West African States (ECOWAS): Is There a Causal Relationship?", Contemporary Economics, Vol. 9, No. 1, ss. 45-60.

Ades, A., Tella, R. (1997). "National Champions and Corruption: Some Unpleasant Interventionist Arithmetic", The Economic Journal, 107, ss.1023-1042.

Alam, M.S. (1995). "A Theory of Limits on Corruption and some Applications", Kyklos, Vol. 48 , ss. 419-435.

Algan, N., Aktakas, B., Tekin, İ. (2014). "Toplumsal Bir Mesele Olarak Yolsuzluk ve Büyüme Ilişkisi: Türkiye Örneği”, Internatıonal Conference on Eurasıan Economıs, ss.1-10.

Beşel, F., Yardımcıoğlu, F. (2013). Demokrasi ve Yolsuzluk illişkisi: Seçilmiş Ortadoğu Ülkelerinin Analizi, Ortadoğu Yıllığı, ss.443-461, http://ormer.sakarya.edu.tr/ uploads/files/demokrai_ve_yolsuzluk_iliskisi.pdf, (15.08.2017).

Bjornskov, C. (2003). Corruption and Social Capital, Department of Economics Aarhus School of Business, Working Paper ss.03-13.

Brown, S., Shackman, J. (2007). "Corruption and Related Socioeconomic Factors: A Time Series Study", Kyklos, Vol. 60, No. 3, ss.319-347.

Cohen, D., Prusak, L. (2001). In Good Company: How Social Capital Makes Organizations Work, Boston: Harvard Business School Press.

Delavallade, C. (2006). "Corruption and Distribution of Public Spending in Developing Countries", Journal of Economics and Finance, Vol. 30, ss.222-239.

Dridi, M. (2014). "Corruption and Education: Empirical Evidence", International Journal of Economics and Financial Issues, Vol. 4, No. 3, 2014, ss.476-493.

Erkal, G., Akıncı, M., Yılmaz, Ö. (2015). "Politik İstikrarsızlık ve Yolsuzluk İlişkisi: Bir Panel Veri Analizi", Ege Akademik Bakış Dergisi, Cilt: 15, Sayı: 3, ss.327-342.

Erkan, B., Kara, O. (2011), "Yolsuzluk ve Yoksulluk Göstergeleri Arasındaki İlişki: Türkiye Örneği", 12th International Symposium on Econometrics Statistics and Operations Research, Pamukkale University Departmant of Econometrics, ss.120-128.

Fisman, R., Miguel, E. (Çev. Tuncel Öncel) (2011). Ekonomi Haydutları: Yolsuzluk, Şiddet ve Ulusların Yoksulluğu, Ankara: Efil Yayınevi, 1. Basım, Genel Yayın No: 117.

Güney, T. (2015). "Yönetişim ve Sürdürülebilir Kalkınma: OECD Ülkeleri Üzerine Bir Panel Veri Analizi”, Atatürk Üniversitesi İktisadi ve İdari Bilimler Dergisi, Cilt: 29, Sayı: 2, ss.349-363.

Habib, M., Zurawicki, L. (2001). "Country-level investments and the effect of corruption some empirical evidence", International Business Review, Vol. 10, ss.687-700.

Human Development Report 2015, (05.12.2017).

Huntington, S. (1968). Political Order in Changing Societies, New Haven, Ct: Yale University Press. 
Kangal, N. (2013). Sosyal Sermaye Teorileri ve Sosyal Sermaye Kalkınma İlişkisi: Türkiye Örneği, Selçuk Üniversitesi Sosyal Bilimler Enstitüsü İktisat Anabilim Dalı, Yüksek Lisans Tezi.

Klitgaard, R. (1998). "International Cooperation Against Corruption", Finance \& Development, ss.1-6.

Korkmaz, E., Erkal, M.E., Minibaş, T., Baloğlu, T., Yılmaz, B.E., Çak, M. (2001). Türkiye'de Yolsuzluğun Sosyoekonomik Nedenleri Etkileri ve Çözüm Önerileri, İstanbul Ticaret Odası, Yayın No: 2001-35, İstanbul.

Leff, N.H. (1964). "Economic Development through Bureaucratic Corruption", American Behavioral Scientist, 8(3), ss.8-14.

Legatum Institute (November 2015). The Legatum Prosperity Index 2015, https://lif.blob.core.windows.net/lif/docs/default-source/publications/2015legatum-prosperity-index-pdf.pdf?sfvrsn=2, (19.02.2018).

Legatum Institute (2017). The Legatum Prosperity Index 2017 (Eleventh Edition), http://www.prosperity.com/, (19.02.2018).

Macrae, J. (1982). "Underdevelopment and the Economics of Corruption: A Game Theory Approach", World Development, Vol. 10, No.8, ss.677-687.

Mauro, P. (1995). "Corruption and Growth", The Quarterly Journal of Economics, Vol. 110, No. 3, ss.681-712.

Mauro, P. (1998). "Corruption and the composition of government expenditure", Journal of Public Economics, Vol. 69, ss.263-279.

Mbaku, J. \& Paul, C. (1989). "Political instability in Africa: A rent-seeking approach", Public Choice, Vol. 63, ss.63-72.

Özbaran, M.H. (2003). "Yolsuzluk ve Bu Alanda Mücadele Eden Uluslararası Örgütler ve Birimler", Sayıştay Dergisi, Temmuz-Aralık, ss.17-34.

Park, H. (2003). "Determinants of Corruption: A Cross-National Analysis", Multinational Business Review, Vol. 11 Issue: 2, ss.29-48.

Pelligrini, L., Gerlah, R. (2008). "Causes of Corruption : A Survey of Cross-Country Analyses and Extended Results", Economics of Governance, Vol. 9, ss.245-263.

Pozega, Z., Crnkovic, B., Sucic, G. (2011). "Analysıs Of The Impact Of Corruption Index, Education And Social Capital On Economic Development", Management, Vol. 16, 1, ss.23-41.

Saha, S., SU, J. (2012). "Investigating the Interaction Effect of Democracy and Economic Freedom on Corruption: A Cross-Country Quantile Regression Analysis", Economic Analaysis \& Policy, Vol. 42, No. 3, ss.389-396.

Sayan, Ö.ì., Kışlalı, M. (2004). Yolsuzluk Üzerine Ekonometrik Bir Çalışma, Ankara Üniversitesi Siyasal Bilgiler Fakültesi Tartışma Metinleri No. 73, http://www.politics.ankara.edu.tr/dergi/tartisma/2004/murat-kislali.pdf, (15.08.2017). 
Saygılıoğlu, N. (2010). "Değişen Devlet Yapısı Karşısında Yolsuzluk Gerçeği ve Saydamlık Gereği", Dış Denetim Dergisi, ss.21-26.

Serra, D. (2006). "Empirical determinants of corruption: A sensitivity analysis", Public Choice, Vol. 126, ss.225-256.

Shabbır, G., Anwar, M. (2007). "Determinants of Corruption in Developing Countries", The Pakistan Development Review, Vol. 46, No. 4, ss.751-764.

Shaw, P. (2007). "Educational Corruption and Growth", Job Market Paper.

Tanzi, V. (1998). "Corruption Around The World-Causes, Consequences, Scope and Cures", IMF Economic Review, Vol. 45(4), ss. 559-594.

TEPAV (Türkiye Ekonomi Politikaları Araştırma Vakfı) (Aralık 2006). Yolsuzlukla Mücadele TBMM Raporu "Bir Olgu Olarak Yolsuzluk: Nedenler, Etkiler ve Çözüm Önerileri, Yolsuzlukla Mücadele Kitapları-1, 2. Basım, Ankara.

The World Bank (September 1997). Helping Countries Combat Corruption-The Role of The World Bank. Poverty Reduction and Economic Management. Web: http://www1.worldbank.org/publicsector/anticorrupt/corruptn/corrptn.pdf, (24.02.2018).

Tiwari, A.K. (2012). "Corruption, Democracy and Bureaucracy", Theoretical and Applied Economics, Vol. 19, No. 9(574), ss.17-28.

Transparency International (2016). Corruption Perceptions Index 2015, http://www.iaca.int/images/news/2016/Corruption_Perceptions_Index_2015_rep ort.pdf, (22.02.2018).

Transparency International (2016). Corruption Perceptions Index, https://www.transparency.org/what-is-corruption/\#define, (12.01.2018).

Transparency International (2018). Corruption Perceptions Index 2017, file:///C:/Users/admin/Downloads/2017_CPI_Brochure_EN.PDF, (12.01.2018).

Treisman, D. (2000). "The Causes of Corruption: A Cross-National Study", Journal of Public Economics, Vol. 76, ss.399-457.

Türedi, S., Altıner, A. (2016). "Economic and Political Factors Affecting Corruption in Developing Countries", International Journal of Economics and Research, Vol. 7, Issue 1, ss.104-120.

United Nations Development Programme (UNDP) (2016). Human Development Report 2016, New York, http://hdr.undp.org/sites/default/files/2016_human_ development_report.pdf, (01.02.2018).

Yaşar, N. (2016). Enerji Tüketimi ve İktisadi Büyüme Arasındaki illişki, Hacettepe Üniversitesi Sosyal Bilimler Enstitüsü, Doktora Tezi, Ankara.

Yerdelen Tatoğlu, F. (2016). Panel Veri Ekonometrisi, Genişletilmiş 3. Baskı, İstanbul, Beta Basım.

Zakaria, M. (2009). "Openness and Corruption: A Time-Series Analysis", Zagreb International Review of Economics \& Business, Vol. 12(2), ss.1-14. 